\title{
Liver $X$ receptor $\beta$ activation induces pyroptosis of human and murine colon cancer cells
}

\author{
V Derangère ${ }^{1,2,3}$, A Chevriaux $^{1,2}, \mathrm{~F}_{\text {Courtaut }}{ }^{1,3}, \mathrm{M}_{\text {Bruchard }}{ }^{1,3}$, H Berger $^{1,3}, \mathrm{~F}$ Chalmin $^{1,3}$, SZ Causse $^{1}, \mathrm{E}$ Limagne $^{1,3}, \mathrm{~F}$ Végran $^{1,3}$, \\ S Ladoire ${ }^{1,2,3}$, B Simon ${ }^{4}$, W Boireau ${ }^{4}$, A Hichami ${ }^{1,3}$, L Apetoh ${ }^{1,2,3}$, G Mignot ${ }^{1}$, F Ghiringhelli ${ }^{1,2,3,5}$ and C Rébé ${ }^{\star, 1,2,5}$
}

Liver $X$ receptors (LXRs) have been proposed to have some anticancer properties, through molecular mechanisms that remain elusive. Here we report for the first time that LXR ligands induce caspase-1-dependent cell death of colon cancer cells. Caspase1 activation requires Nod-like-receptor pyrin domain containing 3 (NLRP3) inflammasome and ATP-mediated P2 $\times 7$ receptor activation. Surprisingly, LXR $\beta$ is mainly located in the cytoplasm and has a non-genomic role by interacting with pannexin 1 leading to ATP secretion. Finally, LXR ligands have an antitumoral effect in a mouse colon cancer model, dependent on the presence of LXR $\beta$, pannexin 1, NLRP3 and caspase-1 within the tumor cells. Our results demonstrate that LXR $\beta$, through pannexin 1 interaction, can specifically induce caspase-1-dependent colon cancer cell death by pyroptosis.

Cell Death and Differentiation (2014) 21, 1914-1924; doi:10.1038/cdd.2014.117; published online 15 August 2014

Liver $X$ receptor $\alpha(\operatorname{LXR} \alpha)$ and $\beta$ belong to the nuclear receptor family. LXR $\alpha$ is expressed primarily in the liver, intestine, adipose tissue and macrophages, whereas $\operatorname{LXR} \beta$ is widely expressed in all tissues. They function as transcription factors through heterodimerization with retinoid $X$ receptor. After activation by natural ligands, such as oxysterols, they increase the expression of target genes encoding proteins implicated in lipid metabolism and more particularly in cholesterol efflux (e.g., abca1 and abcg1) or fatty acid synthesis (e.g., fas). ${ }^{1}$

It has been shown that LXRs are expressed in different cancer cell types and are implicated in cell proliferation and cell death in vitro and in vivo. In prostate and breast cancer cells, the synthetic ligand of LXR, T0901317, induces a decrease in S-phase-associated kinase protein-2 expression leading in turn to the stabilization of p27 and the arrest of cells in G1 phase. ${ }^{2,3}$ In mice, T0901317 treatment leads to a delay in androgen-dependent and androgen-independent tumor development. ${ }^{3,4}$ More recently, T0901317 has also been described to repress AKT pathway, leading to apoptosis of LNCaP prostate cancer cells. ${ }^{5}$ T0901317 could also reverse oxidized low-density lipoprotein-induced proliferation of many ovarian cancer cell lines ${ }^{6}$ and could disturb cholesterol homeostasis by reducing low-density lipoprotein uptake and upregulating cholesterol efflux, both leading to glioblastoma cell death. ${ }^{7}$ Finally, LXRs were shown to be able to decrease colon cancer cell proliferation through inhibition of the oncogenic activity of $\beta$-catenin ${ }^{8}$ or by modulating the expression of cell cycle regulators. ${ }^{9}$
However, a common feature of these reports is that all these mechanisms only involved the transcriptional activity of LXR. Our study unravels a new non-transcriptional function of LXR and shows that synthetic and natural LXR agonists could induce colon cancer cell death through caspase-1 activation. LXR ligands induce ATP release through a direct interaction of LXR $\beta$ with pannexin 1. Extracellular ATP then activates $\mathrm{P} 2 \times 7$ receptor, leading to caspase- 1 activation using the NOD-like receptor pyrin domain containing 3 (NLRP3) and the adaptor apoptosis-associated Speck-like protein containing a CARD domain (ASC). Finally, T0901317 treatment of tumor-bearing mice slows down tumor progression in an LXR $\beta$-, caspase-1-, NLRP3- and pannexin 1-dependent manner.

\section{Results}

LXR agonists induce colon cancer cell death. We first tested the effect of the LXR agonist T0901317 on cell viability of four human colon cancer cell lines (HCT116, HT29, HCT8 and SW480) that all express both LXR $\alpha$ and $\operatorname{LXR} \beta$ isoforms (Supplementary Figure 1). We showed that this agonist had a dose- and time-dependent effect on cell viability (Figure 1a and Supplementary Figure 2). The effect of T0901317 was largely due to its capacity to induce cell death. Indeed, T0901317 induced apoptotic cell death as measured by phosphatidylserine (PS) exposure (Annexin $\mathrm{V}^{+}$cells) and more importantly necrotic cell death as measured by cell membrane rupture (annexin $\mathrm{V}^{+} / 7-\mathrm{AAD}^{+}$

${ }_{1}^{1}$ Institut National de la Santé et de la Recherche Médicale (INSERM) UMR 866, Dijon 21079, France; ${ }^{2}$ Centre Georges François Leclerc, Dijon 21000, France; ${ }^{3}$ Faculté de Médecine et de Pharmacie, Université de Bourgogne, Dijon 21000, France and ${ }^{4}$ Institut Franche-Comté Electronique, Mécanique, Thermique et Optique-Sciences et Technologies (FEMTO-ST), Département Micro Nano Sciences and Systèmes, Université de Franche Comté, Besançon 25044, France

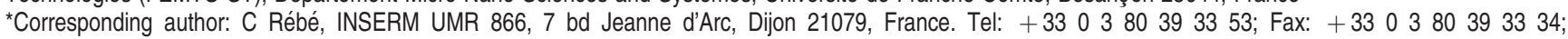
E-mail: crebe@cgfl.fr

${ }^{5}$ These authors share co-senior authorship.

Abbreviations: 7-AAD, 7-amino-actinomycin D; ABCA1, ATP-binding cassette transporter A1; ASC, apoptosis-associated Speck-like protein containing a CARD domain; CARD, caspase activation and recruitment domain; CBX, carbenoxolone; CPIM, complete protease inhibitor mixture; IF, immunofluorescence; LXR, liver X receptor; NLRP3, Nod-like-receptor pyrin domain containing 3; PLA, proximity ligation assay; Prob, probenecid; PS, phosphatidylserine; shRNA, short hairpin RNA; siRNA, small interfering RNA; VDAC, voltage-dependent anion channel

Received 09.12.13; revised 28.6.14; accepted 15.7.14; Edited by M Piacentini; published online 15.8.14 
a

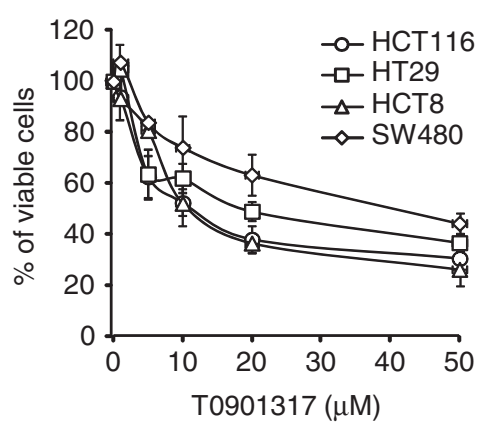

C

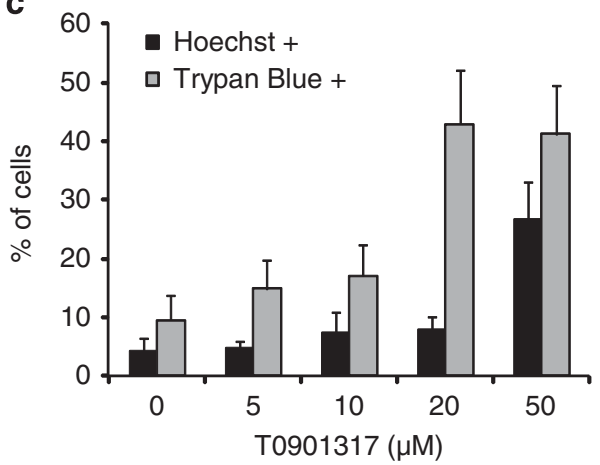

e

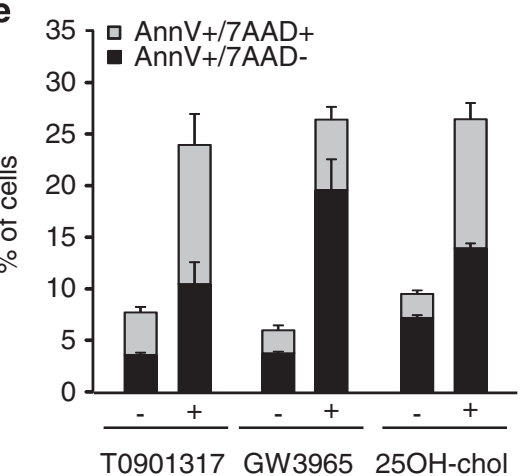

b

HCT116

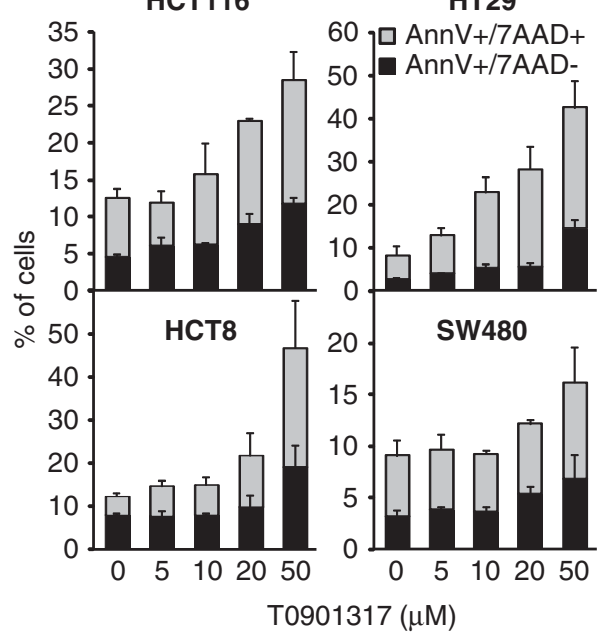

d

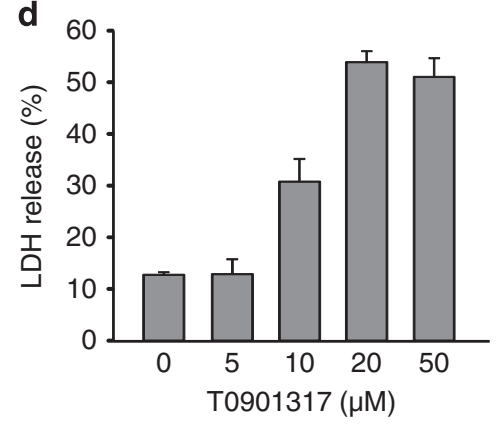

f

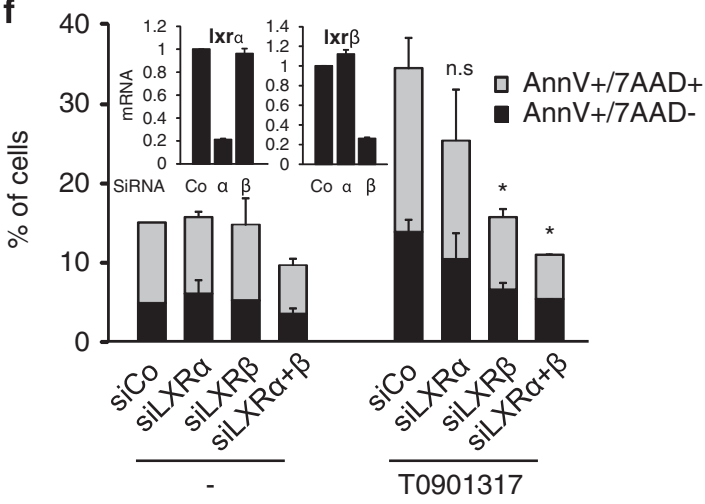

Figure 1 LXR agonists induce human colon cancer cell death by an LXR $\beta$-dependent mechanism. (a and $\mathbf{b})$ Dose-effect of a 24-h T0901317 treatment at indicated concentrations in different human colon cancer cell lines analyzed by (a) crystal violet coloration (cell viability) or (b) Annexin V/7-AAD staining and flow cytometry analysis. (c and d) Dose-effect of a 24-h T0901317 treatment at indicated concentrations in HCT116 cells on (c) the percentage of positive cells for chromatin condensation and fragmentation (Hoechst staining - black bars) or trypan blue staining (gray bars) and (d) LDH release. (e) Percentage of Annexin V/7-AAD-positive HCT116 cells after a 24-h treatment of T0901317 $(20 \mu \mathrm{M})$, GW3965 $(30 \mu \mathrm{M})$ or 25 hydroxycholesterol (25-OH chol, $50 \mu \mathrm{M})$. (f) Effect of LXR siRNA on percentage of Annexin V/7-AAD-positive HCT116 cells after $24 \mathrm{~h}$ of treatment with $20 \mu \mathrm{M}$ of T0901317. Inset: siRNA knockdown efficiency evaluated by QPCR and normalized to a set of housekeeping genes. Data are the mean of at least three independent experiments \pm S.D. Statistics compare T0901317-treated LXR siRNA with T0901317-treated control siRNA: ${ }^{*} P<0.05$, NS, not significant using two-tailed $t$-test

cells; Figure 1b). This was confirmed by the induction of cell permeabilization (Trypan blue staining and $\mathrm{LDH}$ release) and by chromatin condensation and fragmentation (Hoechst staining and subG1 detection; Figures 1c and d and Supplementary Figure 3). Other LXR agonists, such as the synthetic compound GW3965 and the natural ligand 25-hydroxycholesterol $(25 \mathrm{OH}$-chol) also had the capacity to induce cell death in HCT116 cells (Figure 1e). The effect of T0901317 was abrogated by silencing the expression of the isoform $\beta$ (but not isoform $\alpha$ ), showing that it specifically depends on LXR and more particularly on LXR $\beta$ (Figure 1f). These results show that LXR agonists induce colon cancer cell death, and more particularly necrotic-like cell death. 
LXR agonists-induced cell death is mediated by caspase-1. To extend the mechanism responsible for LXR agonist-induced cell death, we first check whether caspases were activated in our model. T0901317 induced an early caspase- 1 activation (within the first hour of treatment) and a late caspase-7 activation, whereas no caspase-3, -8 or -9 activation could be detected, using specific antibodies targeting cleaved/activated caspases by western blot (Figure 2a). This was confirmed with the FLICA fluorescent probes specific for activated caspase-1 or caspase-3/7 (Figure 2b). Caspase-1 activation was also observed with other LXR ligands as assessed by FLICA-1 measurement and also by the detection of the cleaved caspase-1 p20 fragment by western blotting (Figure 2c). LXR $\beta$ silencing inhibited caspase- 1 activation, confirming that $\mathrm{LXR} \beta$ was required for T0901317-mediated effects (Figure 2d). Moreover, the silencing of caspase-1 (by short hairpin RNA (shRNA)) inhibited T0901317-induced cell death and more specifically necrotic-like cell death, as shown by the more important effect of caspase-1 silencing on membrane permeabilization (annexin $\mathrm{V}^{+} / 7-\mathrm{AAD}^{+}$cells) than on PS exposure (annexin $\mathrm{V}^{+} / 7-\mathrm{AAD}^{-}$cells; Figure $2 \mathrm{e}$ ). Caspase- 1 and -7 activations and membrane permeabilization are two main features of pyroptotic cell death. ${ }^{10}$ The involvement of pyroptosis in T0901317-mediated cell death was confirmed by cell swelling until becoming a balloonshaped vesicle around the nucleus (Supplementary Figure 4). Finally, the transcriptional effect of T0901317 on HCT116 cells was tested. We found that mRNA expression of LXR target genes (i.e., srebf1 and abca1) was induced after $24 \mathrm{~h}$ of treatment and not after $1 \mathrm{~h}$ when caspase-1 was already activated. The well-known transcription inhibitor actinomycin $D$ can inhibit these effects on target genes, but had no effect on LXR ligand-mediated cell death (Supplementary Figure 5). All in all, these experiments show that LXR ligands induce pyroptosis of colon cancer cells, independently of any transcription activity.

LXR agonist-induced cancer cell pyroptosis is mediated by the NLRP3 inflammasome-dependent activation of caspase-1. Caspase-1 is classically activated within the a

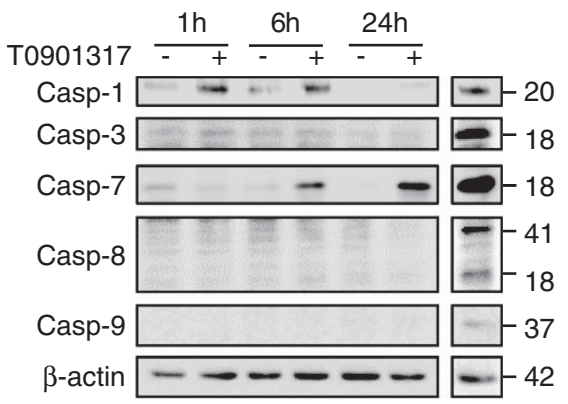

C

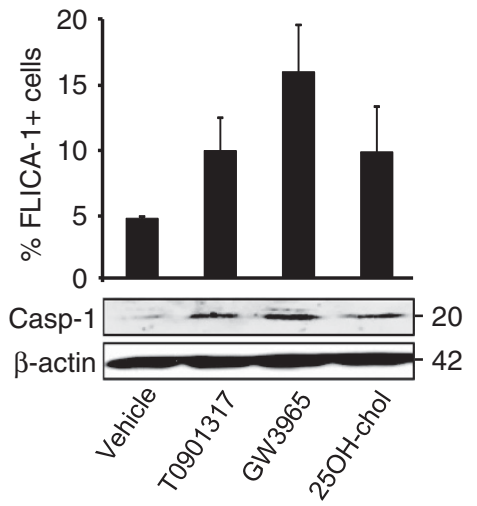

d b
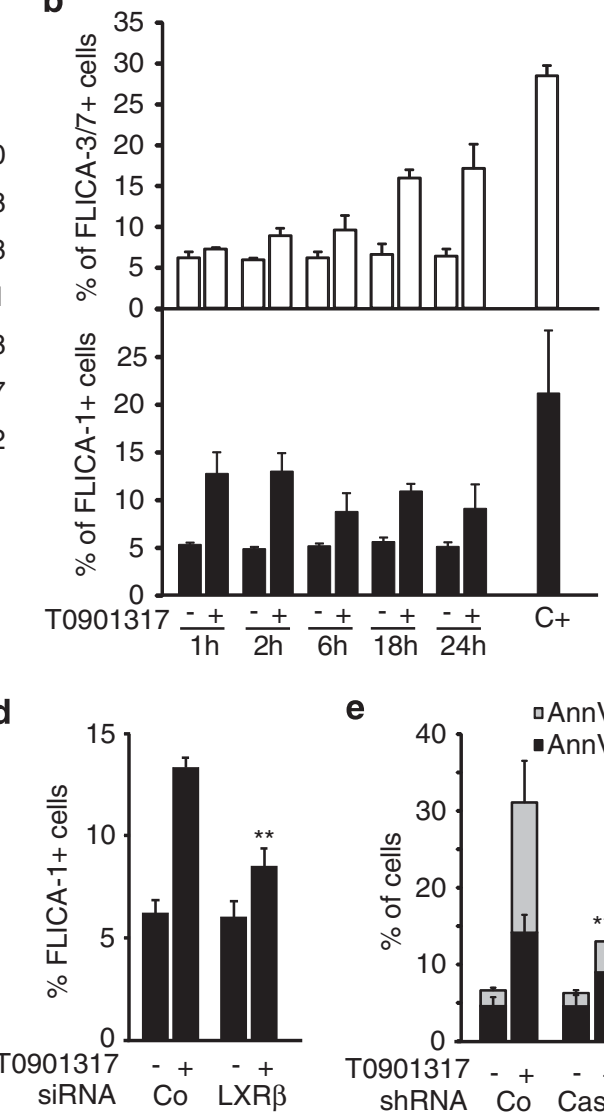

Figure 2 LXR agonists induce human colon cancer cell death by a caspase-1-dependent mechanism. (a) Western blot analysis of cleaved caspase-1, -3, -7, 8 and -9 in HCT116 cells treated with $20 \mu \mathrm{M}$ of T0901317 at indicated times. ATP $(5 \mathrm{mM}-1 \mathrm{~h}$ for caspase- 1$)$ or TRAIL $(200 \mathrm{ng} / \mathrm{ml}-6 \mathrm{~h}$ for other caspases $)$ were used as positive controls $(\mathrm{C}+$ ). $\beta$-Actin was used as a loading control. Numbers indicate molecular masses in kilodaltons. (b) Measurement of caspase- 1 or caspase-3/7 activation in HCT116 cells treated with $20 \mu \mathrm{M}$ of T0901317 at indicated times by FLICA-1 or FLICA-3/7 staining and flow cytometry analysis. ATP $(5 \mathrm{mM}-1 \mathrm{~h})$ or Staurosporine $(2 \mu \mathrm{M}-18 \mathrm{~h})$ were used as positive controls $(C+)$. (c) Measurement of caspase-1 activation after a 1-h treatment using LXR agonists (as in Figure 1e), using FLICA-1 staining (upper panel) and western blotting (lower panel). $\beta$-Actin was used as a loading control. Numbers indicate molecular masses in kilodaltons. (d) Effects of LXR $\beta$ siRNA on caspase-1 activation (FLICA-1) in HCT116 cells treated for $1 \mathrm{~h}$ with $20 \mu \mathrm{M}$ of T0901317. (e) Effects of caspase-1 shRNA on the percentage of Annexin V/7-AAD-positive HCT116 cells after $24 \mathrm{~h}$ of treatment with $20 \mu \mathrm{M}$ of T0901317. Data are the mean of at least three independent experiments \pm S.D. Statistics compare T0901317-treated controls with other treated conditions: ${ }^{* \star} P<0.005,{ }^{* * *} P<0,001$, using two-tailed $t$-test 
macromolecular complex called inflammasome. The wellcharacterized NLRP3 inflammasome (which contains NLRP3, ASC and caspase-1) is known to be activated by autologous signals. ${ }^{11}$ All the NLRP3 inflammasome components were expressed in colon cancer cells (Figure 3a). One of the main inflammasome activation marker is the oligomerization of ASC in a large structure called ASC pyroptosome, which could be isolated by chemical crosslinking with disuccinimidyl suberate. ${ }^{12}$ HCT116 cell treatment by T0901317 induced the formation of ASC pyroptosome after $1 \mathrm{~h}$ of treatment (Figure $3 \mathrm{~b}$ ). Moreover, silencing NLRP3 or ASC decreased the ability of T0901317 to induce cell membrane permeabilization and caspase-1 activation, suggesting that the NLRP3 inflammasome is required for caspase-1 activation and pyroptosis induction in our model (Figure 3c). The NLRP3 inflammasome assembly can be mediated by ROS production, lysosome permeabilization (and cathepsin B activation) or activation of the ATPmediated $\mathrm{P} 2 \times 7$ receptor pathway. ${ }^{11}$ The inhibition of ROS generation (with $N$-acetyl cystein or apocynin or by silencing voltage-dependent anion channel (VDAC)-1 or VDAC2), lysosome acidification (with bafilomycin A) or cathepsin B activation (with CA-074Me) had no effect (Figure 3d and Supplementary Figure 6). On the other hand, the inhibition of P2 $\times 7$ pathway using oxidized ATP (an antagonist of the $\mathrm{P} 2 \times 7$ receptor) limited the cytotoxic effect and caspase- 1 activation induced by T0901317 (Figure 3d). The importance of $\mathrm{P} 2 \times 7$ was confirmed by silencing its expression (Figure 3e). Overall, T0901317 induces cancer cell pyroptosis through P2 $\times 7$-mediated NLRP3 inflammasome activation of caspase-1.

ATP release is required for $L X R$ agonist-induced caspase- 1 activation and cancer cell death. Because $P 2 \times 7$ activation can be mediated by extracellular ATP, ${ }^{13}$ we tested whether LXR agonists could induce ATP release from colon cancer cells. Indeed, T0901317, GW3965 and 25OH-chol were all able to induce transient ATP release from HCT116 a

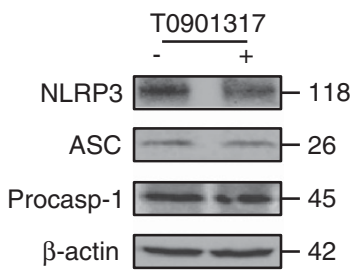

b T0901317 (hours)

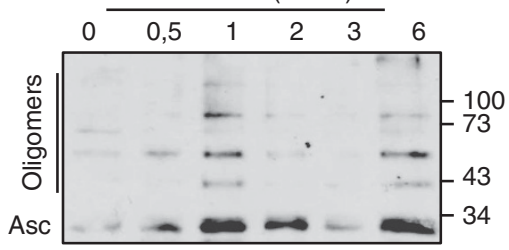

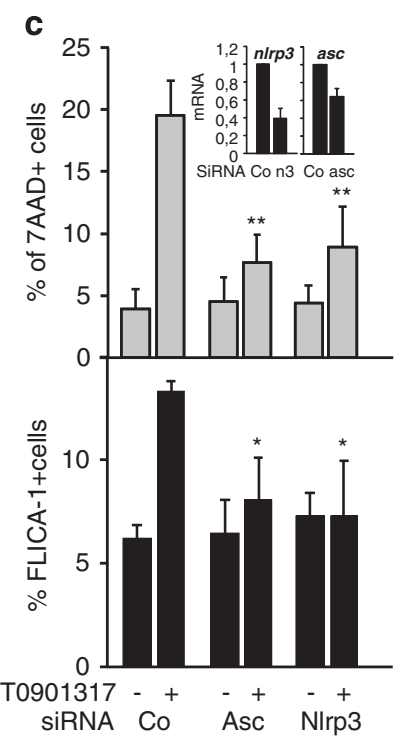

d

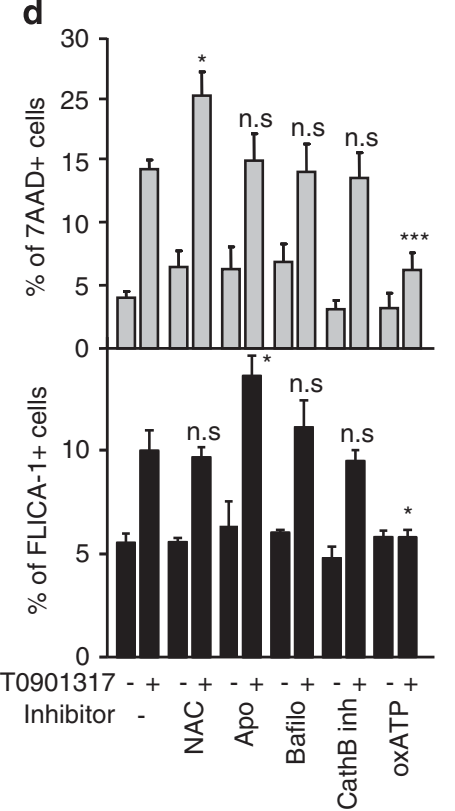

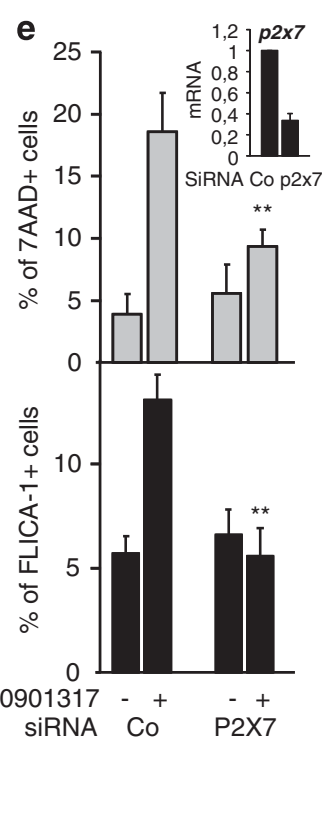

Figure 3 LXR agonists induce NLPR3 inflammasome-mediated caspase-1 activation and cell death by a P2 $\times 7$-dependent mechanism. (a) Western blot analysis of NLRP3, procaspase-1 and ASC expression in HCT116 cells treated or not for $1 \mathrm{~h}$ with $20 \mu \mathrm{M}$ of T0901317. $\beta$-Actin was used as a loading control. Numbers indicate molecular masses in kilodaltons. (b) Western blot analysis of ASC crosslinked pellets in HCT116 treated with $20 \mu \mathrm{M}$ of T0901317 at indicated times. Numbers indicate molecular masses in kilodaltons. (c-e) After siRNA transfection or inhibitor pretreatments, HCT116 were treated with $20 \mu \mathrm{M}$ of T0901317 for $24 \mathrm{~h}$ and stained with 7-AAD (cell death) or treated for $1 \mathrm{~h}$ with $20 \mu \mathrm{M}$ T0901317 and stained with FLICA-1 (caspase-1 activity). (c) Effects of siRNA targeting the inflammasome components ASC and NLRP3 on 7-AAD- (upper panel) or FLICA-1- (lower panel) positive HCT116 cells after T0901317 treatments. Inset: siRNA knockdown efficiency evaluated by QPCR and normalized to a set of housekeeping genes. (d) Effects of NLRP3 inflammasome inhibitors NAC (10 mM), Apocynin (100 $\mu \mathrm{M})$, Bafilomycin A1 (10 nM), Cathepsin B inhibitor (CA074Me, $33 \mu \mathrm{M})$ and oxidized ATP $(300 \mu \mathrm{M})$ on 7-AAD- (upper panel) or FLICA-1- (lower panel) positive HCT116 cells. (e) Effects of siRNA targeting P2 $\times 7$ on 7-AAD (upper panel) or FLICA-1 (lower panel)-positive HCT116 cells. Inset: siRNA knockdown efficiency as in c. Data are the mean of at least three independent experiments \pm S.D. Statistics compare T0901317-treated conditions with T0901317-treated controls: ${ }^{*} P<0.05,{ }^{* *} P<0.005,{ }^{* * *} P<0,001$, NS, not significant using two-tailed $t$-test 
cells, within the first $10 \mathrm{~min}$ of ligand exposure (Figures $4 \mathrm{a}$ and $b$ ). ATP release has been described to be mediated through the opening of pannexin 1 channel. ${ }^{14}$ T0901317 was able to induce pannexin 1 opening as assessed by YO-PRO1 internalization (Supplementary Figure 7). In addition, the pharmacological inhibition of pannexin 1 with carbenoxolone (CBX) or probenecid (Prob) or the silencing of pannexin 1 expression with small interfering RNA (siRNA) inhibited ATP release (Figures $4 \mathrm{c}$ and $\mathrm{d}$ ), showing that pannexin 1 is implicated in T0901317-mediated ATP release. This effect was also dependent on the $\beta$ isoform of LXR as $\operatorname{LXR} \beta$ silencing also inhibited ATP release from HCT116 cells (Figure 4d). Finally, inhibition of pannexin 1-mediated ATP release using inhibitors (Figures $4 \mathrm{e}$ and $\mathrm{f}$ ) or siRNA (Figures

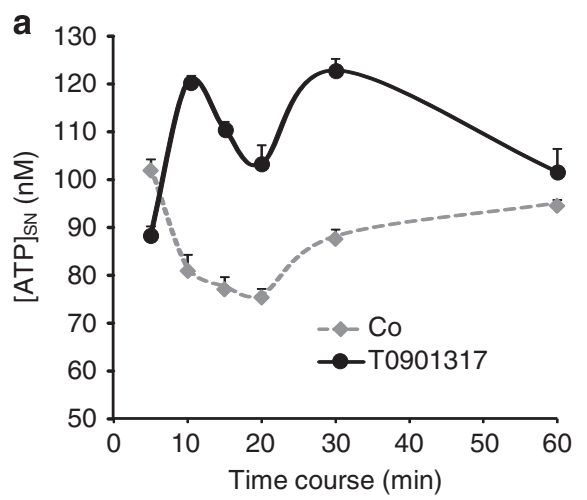

b

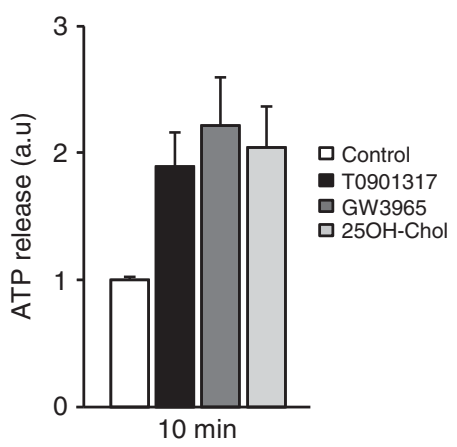

C
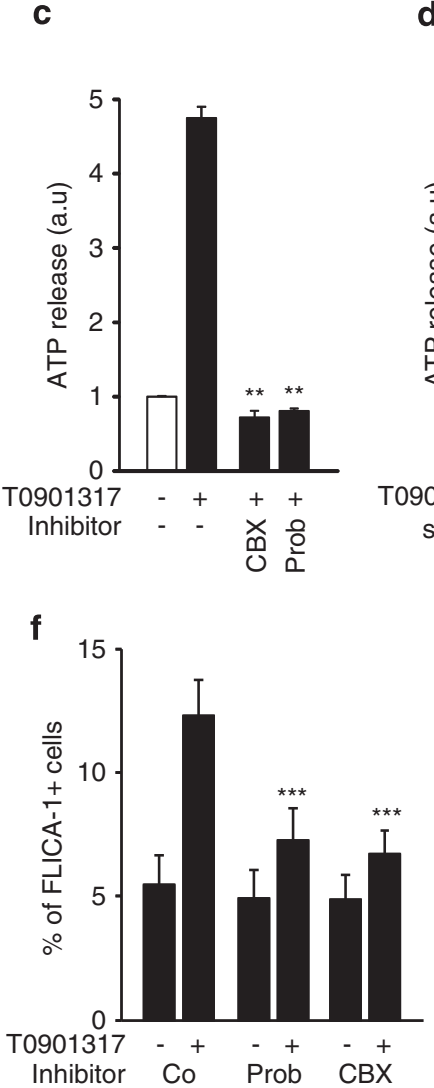

d
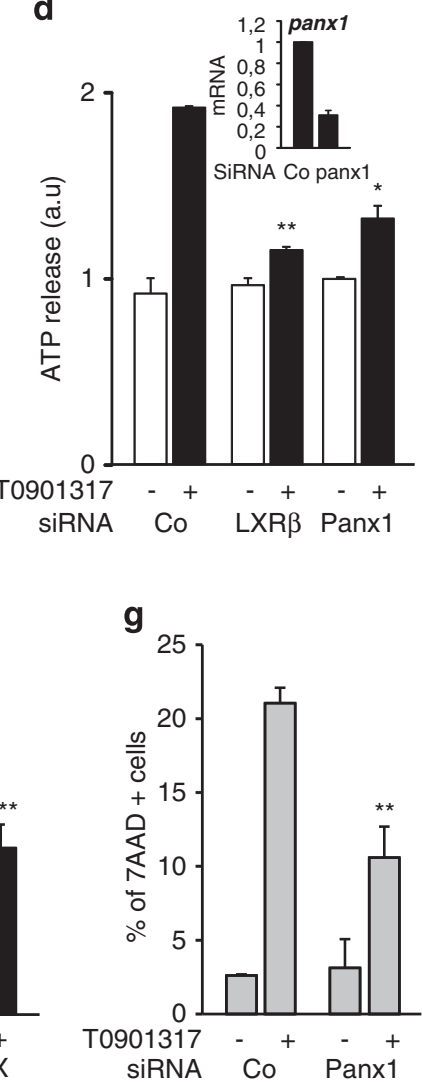

e

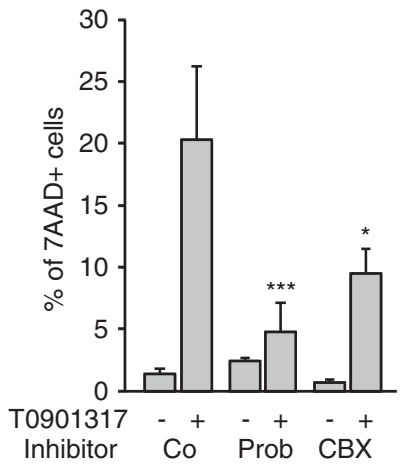

h

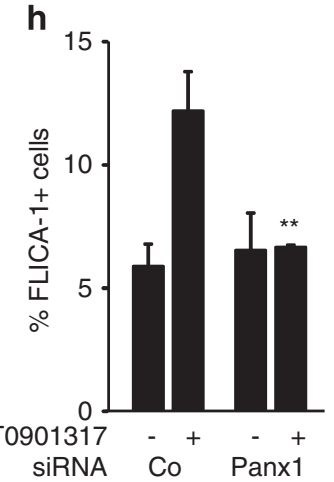

Figure 4 LXR agonists induce ATP release through pannexin 1. (a and b) ATP quantification in HCT116 cell supernatant after a $20 \mu \mathrm{M} \mathrm{T0901317} \mathrm{treatment} \mathrm{at} \mathrm{indicated}$ times (a) or after T0901317 $(20 \mu \mathrm{M})$, GW3965 $(30 \mu \mathrm{M})$ or 25 hydroxycholesterol $(25 \mathrm{OH}-\mathrm{chol}, 50 \mu \mathrm{M})$ treatments for $10 \mathrm{~min}$ (b). (c and d) ATP quantification in HCT116 cell supernatants after carbenoxolone (CBX, $100 \mu \mathrm{M})$ or probenecid (Prob, $500 \mu \mathrm{M})$ pretreatments (c) or siRNA targeting LXR $\beta$ or pannexin 1 (panx1) transfection (d) and subsequent T0901317 treatment at $20 \mu \mathrm{M}$ for $10 \mathrm{~min}$. Inset: siRNA knockdown efficiency evaluated by QPCR and normalized to a set of housekeeping genes. (e and f) Effects of CBX $(100 \mu \mathrm{M})$ or probenecid (Prob, $500 \mu \mathrm{M})$ on 7-AAD-positive HCT116 cells after $24 \mathrm{~h}$ of treatment with $20 \mu \mathrm{M}$ T0901317 (e) or FLICA-1-positive HCT116 cells after $1 \mathrm{~h}$ of treatment with $20 \mu \mathrm{M}$ T0901317 (f). (g and $\mathbf{h}$ ) Effects of pannexin 1 siRNA on 7-AAD-positive HCT116 cells after a $20 \mu \mathrm{M}$ T0901317 treatment of $24 \mathrm{~h}$ (g) or FLICA-1-positive HCT116 cells after a $20 \mu \mathrm{M}$ T0901317 treatment of $1 \mathrm{~h}(\mathrm{~h})$. For ATP release, data are representative of at least three independent experiments \pm S.D. For other experiments, data are the mean of three independent experiments \pm S.D. Statistics compare T0901317-treated conditions with T0901317-treated controls: ${ }^{*} P<0.05$, ${ }^{* \star} P<0.005$, ${ }^{* \star *} P<0,001$, using two-tailed $t$-test 
$4 \mathrm{~g}$ and $\mathrm{h}$ ) also impeded T0901317-induced cell death and caspase-1 activation. Thus, LXR agonists induce ATPdependent caspase-1 activation through pannexin 1 channel opening.

LXR agonist mediates the interaction of LXR $\beta$ with pannexin 1. We next wondered how activated LXR $\beta$ can directly open pannexin 1. We first showed that $\operatorname{LXR} \beta$ was partly localized at the plasma membrane level, as detected by the co-localization of $\operatorname{LXR} \beta$ with cholera toxin in untreated HCT116 cells by immunofluorescence (IF) studies (Figure 5a). Moreover, we isolated plasma membrane-enriched fractions from untreated or T0901317-treated HCT116 cells. At the basal level, such as pannexin $1, \operatorname{LXR} \beta$ was already present in this fraction but no accumulation of $L X R \beta$ at the membrane could be observed under T0901317 treatment (Supplementary Figure 8). Second, surface plasmon resonance experiments suggested that $\mathrm{LXR} \beta$ and the C-terminal domain of pannexin 1 could associate in vitro (Figure $5 \mathrm{~b}$ ). Co-immunoprecipitation experiments also support this observation, as LXR $\beta$ could interact with endogenous pannexin 1 within 10 min of T0901317 treatment (Figure 5c and Supplementary Figure 9). This interaction was confirmed in HCT116 cells by proximity ligation assay (PLA) as observed with the presence of fluorescent dots (representative of LXR $\beta$-pannexin 1 heterodimerization foci) at the plasma membrane level in cells treated for $10 \mathrm{~min}$ with T0901317 (Figures $5 d$ and e). Thus, all these experiments show that $\mathrm{LXR} \beta$ interacts with pannexin 1 to trigger ATP release.

LXR agonist reduces tumor growth in mice. With the objective to determine whether LXR agonists could also have an effect on tumor growth in vivo, we tested the effect of T0901317 on murine CT26 colon cancer cells. First, we observed that T0901317 induced pyroptosis stigmata, that is, membrane permeabilization and caspase- 1 activation, in CT26 cells in vitro (Figures $6 a$ and $b$ ). These phenomena were abrogated when $\mathrm{LXR} \beta$, NLRP3 or caspase- 1 were silenced (Figures $6 \mathrm{a}$ and $\mathrm{b}$ ). As observed in human colon cancer cells, T0901317 was also able to induce transient a
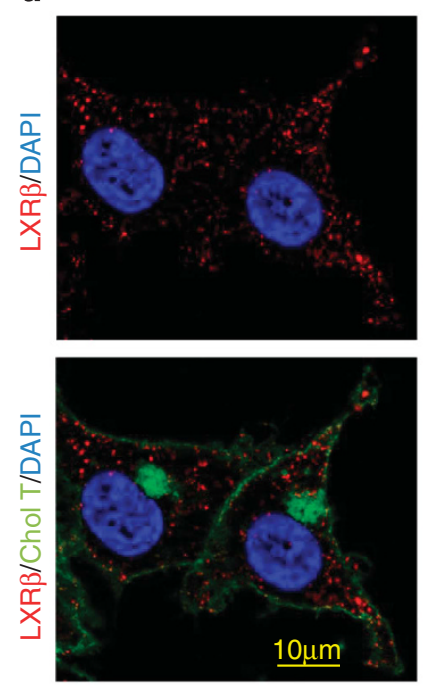

d

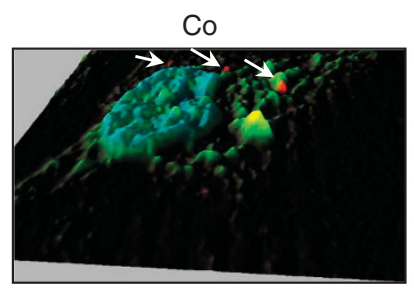

PLA LXRß-Panx1/Chol T/DAPI b

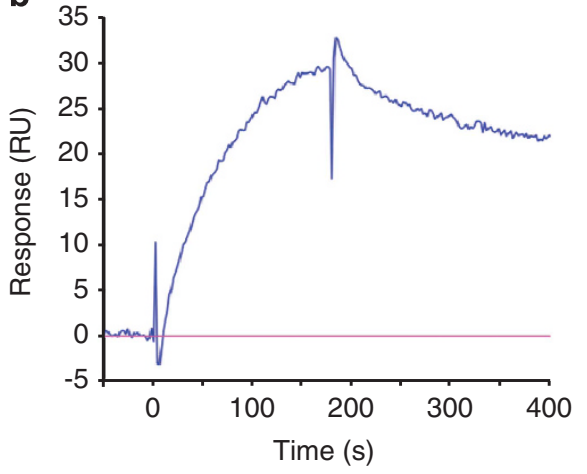

C

IP LXR $\beta$

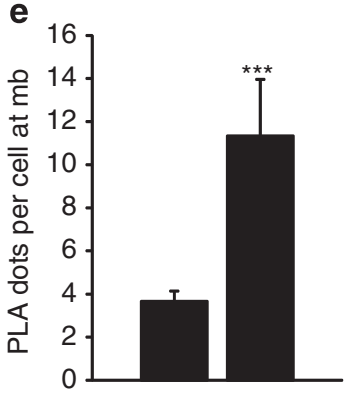

T0901317

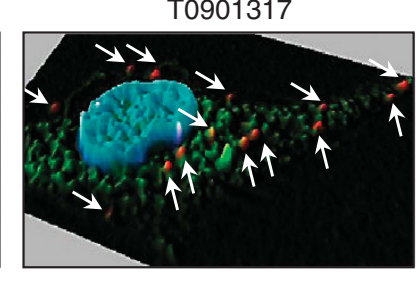

T0901317

Figure 5 LXR agonists induce LXR $\beta$ and pannexin 1 interaction. (a) HCT116 immunofluorescent staining for LXR $\beta$ alone (red, upper panel) or with cholera toxin (Chol T, green, lower panel). (b) Surface plasmon resonance analysis of the binding of LXR $\beta$ to the C-terminal part of pannexin 1 protein chip (blue curve) and with RSA control chip (pink curve). (c) Immunoprecipitation using LXR $\beta$ antibody on HCT116 cells treated or not during the indicated times with $20 \mu \mathrm{M}$ T0901317 and followed by western blot analysis using anti-LXR $\beta$ and anti-pannexin 1 antibodies. Beads (B) are negative controls without antibody for IP. Numbers indicate molecular masses in kilodaltons. (d and $\mathbf{e}$ ) Proximity ligation assay (PLA) performed on HCT116 treated or not during 10 min with $20 \mu \mathrm{M}$ T0901317 with cholera toxin staining. (d) 3D-representation of one cell. (e) Quantification of PLA dots localized in cholera toxin embossments. (a-d) Data are representative of one out of at least three independent experiments. (e) Data are the mean of three independent experiments \pm S.D. with ${ }^{* * *} P<0.001$ using two-tailed $t$-test 

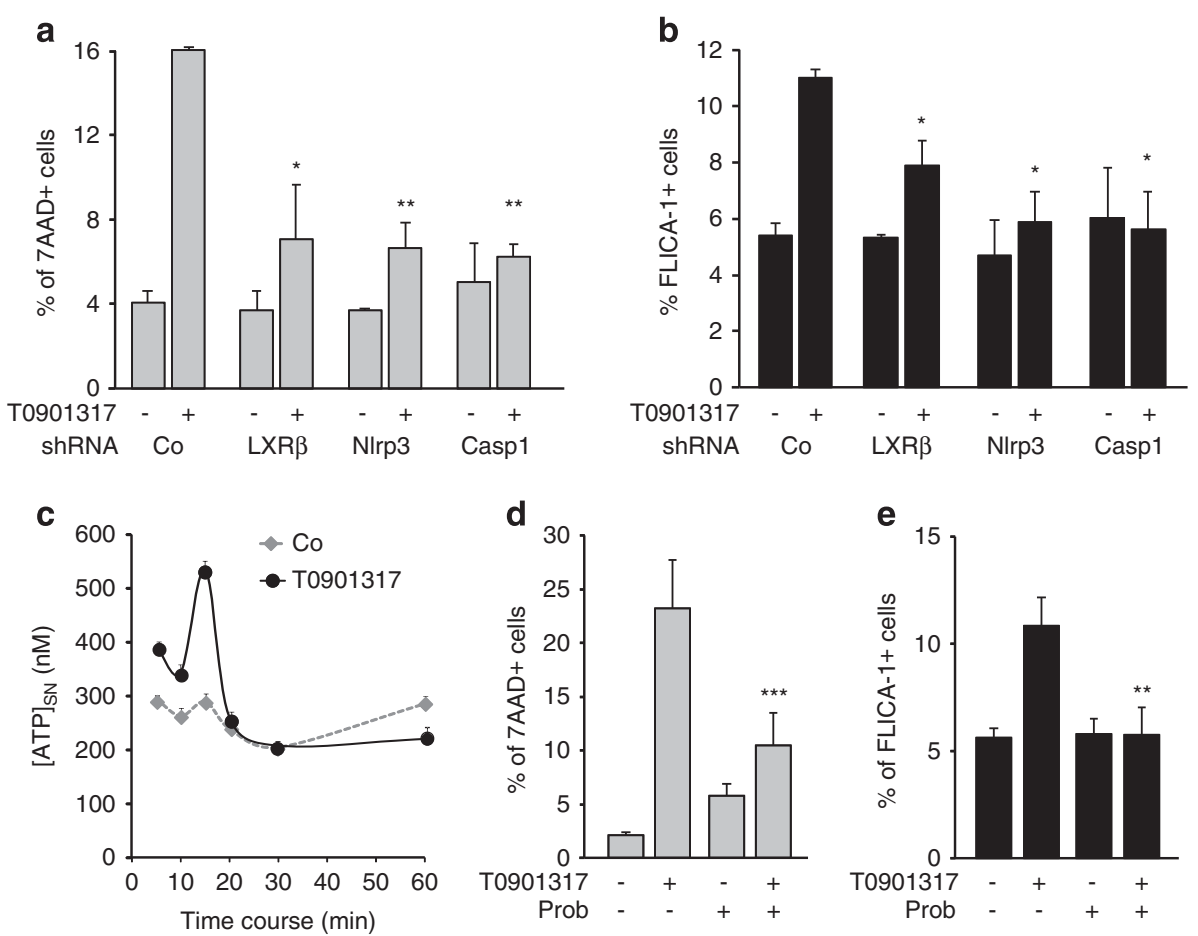

Figure 6 LXR agonists induce murine colon cancer cell death by an LXR $\beta /$ pannexin 1/NLRP3/Caspase-1-dependent mechanism. (a) Effects of LXR $\beta$, Nirp3 or caspase-1 shRNA on the percentage of 7-AAD-positive CT26 cells after $24 \mathrm{~h}$ of treatment with $20 \mu \mathrm{M}$ of T0901317. (b) Effects of LXR $\beta$, Nlrp3 or caspase-1 shRNA on the percentage of FLICA-1-positive CT26 cells after $1 \mathrm{~h}$ of treatment with $20 \mu \mathrm{M}$ of T0901317. (c) ATP quantification in CT26 cell supernatants after a $20 \mu \mathrm{M}$ T0901317 treatment at indicated times. (d and e) Effects of carbenoxolone (CBX, $100 \mu \mathrm{M}$ ) or probenecid (Prob, $500 \mu \mathrm{M}$ ) on 7-AAD-positive CT26 cells after a $20 \mu \mathrm{M}$ T0901317 treatment of $24 \mathrm{~h}$ (d) or FLICA1-positive CT26 cells after a $20 \mu \mathrm{M}$ T0901317 treatment of $1 \mathrm{~h}$ (e). Data are the mean of at least three independent experiments \pm S.D. except for ATP release with one representative of three independent experiments. Statistics compare T0901317-treated conditions with T0901317-treated controls: ${ }^{*} P<0.05,{ }^{* *} P<0.005$, ${ }^{* * *} P<0,001$, using two-tailed $t$-test

ATP release (Figure 6c) and the pannexin 1 inhibitor Prob could also block LXR agonist-mediated cell death and caspase-1 activation (Figures $6 \mathrm{~d}$ and e). To determine whether LXR agonists could have an effect on tumors, Balb/c mice were s.c. injected with CT26 cells, treated i.p. with Prob or vehicle. After 20 days, tumors were collected, dissociated and treated or not with T0901317 ex vivo. We observed that caspase- 1 was specifically activated by T0901317 in CD45 ${ }^{-}$tumor cells, and not in CD45 ${ }^{+}$ hematopoietic infiltrating cells in a pannexin 1-dependent manner (Supplementary Figure 10). Then, Balb/c mice s.c. injected with CT26 cells were daily treated i.p. with 30 or $60 \mathrm{mg} / \mathrm{kg}$ T0901317 or the vehicle. T0901317-treated mice presented a reduced tumor growth compared with tumorbearing mice treated with the vehicle (Figure 7a). This observation correlated with a higher caspase-1 activation in tumor cells from T0901317-treated mice (Figure 7b). Moreover, the tumor growth was not affected by LXR agonist when mice were treated concomitantly with Prob, suggesting that pannexin 1 was involved in T0901317-mediated effects on tumor growth (Figure 7c). Finally, we observed that T0901317 had no effect on tumor growth when CT26 cells were transfected with shRNA targeting LXR $\beta$, NLRP3 or caspase-1, as compared with cells transfected with control shRNA (Figure 7d). Altogether, our results demonstrate that T0901317 can reduce tumor growth by inducing LXR $\beta$-, pannexin 1- and NLRP3-dependent caspase-1 activation pathway, specifically in tumor cells.

\section{Discussion}

This study reports for the first time that LXR agonists can induce the association of $\operatorname{LXR} \beta$ with pannexin 1 in colon cancer cells. This interaction triggers the opening of pannexin 1 and subsequent ATP release. Then, extracellular ATP activates the $\mathrm{P} 2 \times 7$ pathway, leading to caspase- 1 activation through assembly of the NLRP3 inflammasome and eventually to cell death (Figure 8). The LXR agonist-induced features are characteristics of pyroptosis, that is, ATP release, caspase-1 activation and to a less extent late caspase-7 activation, membrane permeabilization and chromatin fragmentation. ${ }^{10}$ To our knowledge, this is the first time that pyroptosis could be chemically induced in cancer cells, without any bacterial or viral infection. Moreover, the treatment of tumor-bearing mice with LXR agonist decreases tumor growth in an LXR $\beta$-, caspase-1-, NLRP3- and pannexin 1-dependent manner.

It has been previously suggested that LXR could be a powerful target in cancer treatment. ${ }^{15}$ Many studies have shown that LXR agonists could inhibit cancer cell proliferation by modulating cell cycle protein expression ${ }^{2,8,9,16}$ and/or induce cancer cell death, mainly through caspase-3-dependent apoptosis. ${ }^{5,7}$ We demonstrate here for the first time that LXR agonist activation of LXR $\beta$ can induce pyroptotic cell death through an NLRP3 inflammasome-dependent caspase1 activation pathway. This effect seems to be quite surprising, as many studies report that LXR is mainly a negative regulator of inflammation by downregulating the expression of selective 

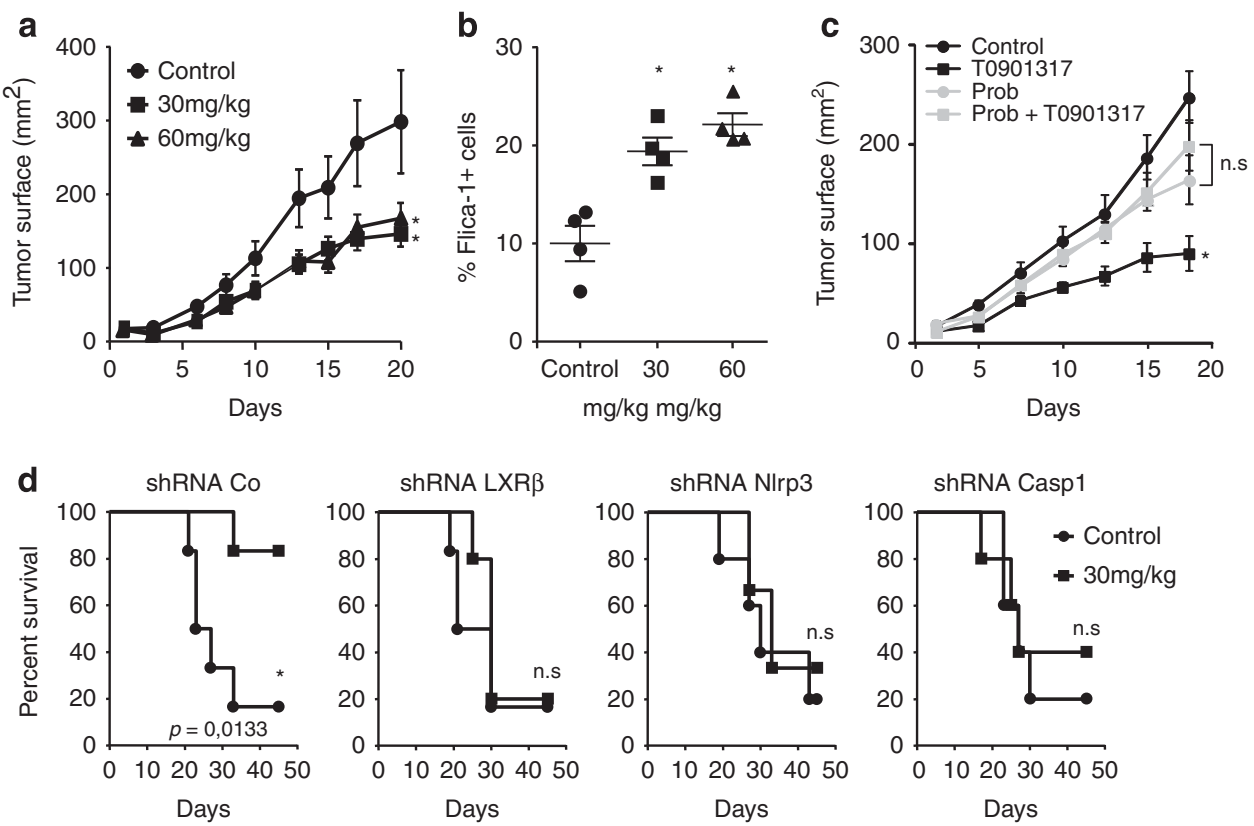

Figure 7 LXR ligands mediate a decrease in mice tumor growth through an LXR $\beta /$ pannexin 1/NLRP3/caspase-1-dependent manner. (a and $\mathbf{b})$ Effects of daily i.p. injections of 30 or $60 \mathrm{mg} / \mathrm{kg} \mathrm{T0901317} \mathrm{on} \mathrm{tumor} \mathrm{growth} \mathrm{of} \mathrm{CT26} \mathrm{tumor-bearing} \mathrm{Balb/c} \mathrm{mice} \mathrm{(a)} \mathrm{and} \mathrm{FLICA-1-positive} \mathrm{cells} \mathrm{in} \mathrm{the} \mathrm{tumor} \mathrm{at} \mathrm{the} \mathrm{end} \mathrm{of} \mathrm{the} \mathrm{experiment}$ (20 days; b). (c) Effects of daily i.p. injections of $30 \mathrm{mg} / \mathrm{kg} \mathrm{T0901317} \mathrm{with} \mathrm{or} \mathrm{without} 200 \mathrm{mg} / \mathrm{kg}$ probenecid on tumor growth of CT26 tumor-bearing Balb/c mice. (d) Effects of daily i.p. injections of $30 \mathrm{mg} / \mathrm{kg}$ T0901317 on overall survival of Balb/c mice s.c. injected with CT26 transfected either with control shRNA (shRNA Co) or shRNA targeting LXR $\beta$, NIrp3 or caspase-1. Data are representative of one out of three (a and $\mathbf{b}$ ) or one out of two (c and $\mathbf{d}$ ) independent experiments and are the mean \pm S.E.M. Statistics compare T0901317-treated mice with untreated mice: ${ }^{*} P<0.05$, NS, not significant, using two-tailed $t$-test. (d) Statistics compare T0901317-treated mice with untreated mice using log rank (Mantel-Cox) survival test (NS, not significant)

inflammatory genes (e.g., il1b, il6, inos, cox2, mmp9, mcp1, mcp3) through a process that involves DNA interaction, known as transrepression. ${ }^{17,18}$ Here we show that $\operatorname{LXR} \beta$ is localized in the cytoplasm and has a non-genomic effect on the plasma membrane pore pannexin 1 (by direct interaction and activation) within the first minutes of agonist treatment, ruling out any transcriptional activity of LXR in our model. Some non-genomic effects of $\operatorname{LXR} \beta$ were previously described. First, LXR ligands present anti-thrombic effects, through interaction of $\operatorname{LXR} \beta$ with Syk, PLC- $\gamma 2$ and peroxisome proliferator-activated receptor- $\gamma$ leading to the regulation of platelet functions. ${ }^{19}$ Second, Hozoji et al. described that in THP-1 cells, LXR $\beta$ is associated with ATP-binding cassette transporter $\mathrm{A} 1$ (ABCA1) at the plasma membrane level and that under agonist treatment, LXR $\beta$ dissociates from ABCA1 to promote cholesterol efflux and translocates to the nucleus to exert its transcriptional activity. ${ }^{20,21}$

The cytoplasmic and sub-membrane localization of $\operatorname{LXR} \beta$ could account for its interaction with the intra-cellular C-terminal domain of pannexin 1. Chekeni et al. have described that this domain is responsible for the maintaining of the closed conformation of this pore and that the cleavage of this portion by caspase- 3 leads to the opening of pannexin 1 and ATP release..$^{14}$ Our results suggest that the opening of pannexin 1 could not only be induced by caspase-3 cleavage and removal of the $\mathrm{C}$-terminal domain, but also by the ability of $\operatorname{LXR} \beta$ to cover this domain.

The importance of inflammasome components in colon cancer carcinogenesis was reported in colitis-associated cancer experiments. ${ }^{22-24}$ These studies show that mice deficient in NLRP3, ASC or caspase-1 were more susceptible to colitis and colitis-associated cancer. This effect is partially due to the hematopoietic compartment, but Zaki et al. demonstrated that NLRP3 signaling in non-hematopoietic cells (mucosal epithelial cells) is critical for protection against dextran sulfate sodium injury. ${ }^{23}$ Even if the effects of NLRP3 in this context are dependent on caspase-1 and mature IL-18, the real molecular mechanisms and its effects on established tumors remain unknown. Here we provide evidences for the importance of NLRP3, caspase-1 and ASC within cancer cells themselves in the effects of LXR agonist on tumoral growth in vivo and on cell death in vitro.

Recently, it has been demonstrated that activation of caspase- 1 not only leads to inflammation, but in certain circumstances causes an inflammatory form of cell death called pyroptosis. Pyroptosis was first described in myeloid cells infected by pathogens or bacteria and was also characterized by an early membrane permeabilization and the release of the cytoplasmic content into the extracellular environment acting as a danger signal for neighboring immune cells. ${ }^{25}$ Among these signals, pyroptotic cells can release 'find-me signals', such as ATP, that will attract macrophages and facilitate the phagocytosis of dead cells. ${ }^{26}$ In addition, we have previously shown that LXR agonists could induce the expression of transglutaminase 2 in macrophages, through an LXR $\alpha / \operatorname{RAR} \alpha$-dependent mechanism, leading to an increased efficacy of dead cell efferocytosis. ${ }^{27}$ This raises the hypothesis that LXR ligands could control cancer cell growth (1) by inducing LXR $\beta$-dependent pyroptosis of cancer cells and (2) by activating LXR $\alpha$ in macrophages and promoting the phagocytosis of dying cancer cells. 


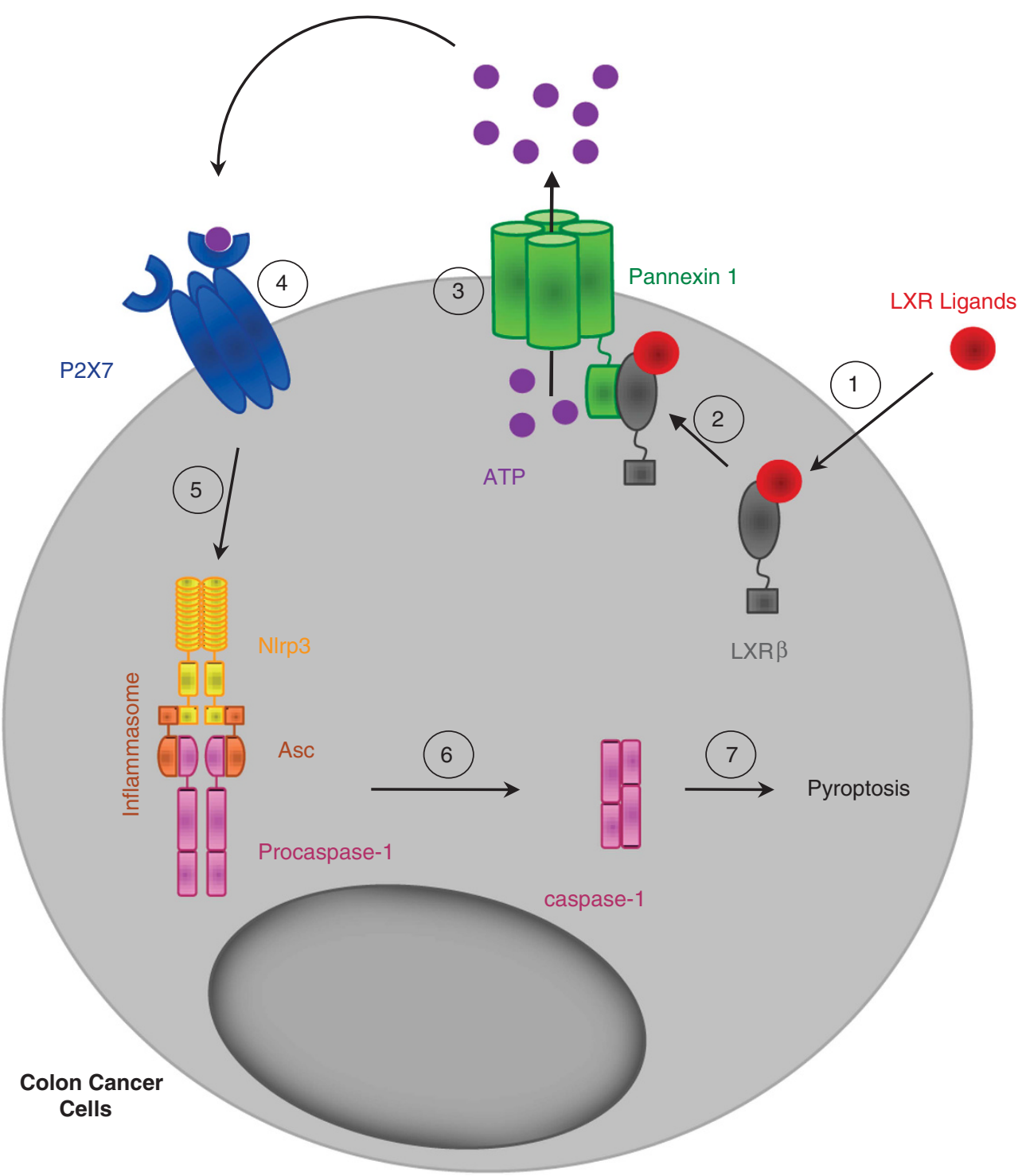

Figure 8 Proposed model for LXR ligand-mediated colon cancer cell death. (1) LXR ligands bind LXR $\beta$ leading to (2) its association with pannexin 1. (3) Then pannexin 1 is opened and allows ATP release. (4) Extracellular ATP binds P2 $\times 7$ receptor, leading to (5) Nlrp3 inflammasome assembly (with Asc) and (6) caspase-1 activation. (7) Activated caspase-1 in turn induces colon cancer pyroptosis

\section{Materials and Methods}

Cell culture. The human colorectal carcinoma HCT116, colorectal adenocarcinoma HT29, HCT8 and SW480, murine colon carcinoma CT26 and epithelial human HEK293T cells were obtained from the American Type Culture Collection. All colon cancer cell lines were grown in RPMI 1640 with ultraglutamine (Lonza, Basel, Switzerland) supplemented with $10 \%$ (vol/vol) fetal bovine serum (Lonza) and with Pen/Strep Amphotericin B (Lonza) 1\%. HEK293T cells were grown in DMEM $4.5 \mathrm{~g} / \mathrm{l}$ glucose (Lonza) with $10 \%$ fetal bovine serum. All cell lines were grown in an atmosphere of $95 \%$ air and $5 \% \mathrm{CO}_{2}$ at $37^{\circ} \mathrm{C}$.

Reagents. T0901317 was purchased from Bertin Pharma and dissolved in DMSO (Sigma-Aldrich, Lyon, France). GW3965 (G6295) and 25OH-chol, H1015) were purchased from Sigma-Aldrich. GW3965 was dissolved in DMSO and 25OHchol in 100\% ethanol. Staurosporine, Oxidized ATP (A 6779), Bafilomycin A1 (B1793), CBX (C4790), N-acetyl cysteine (A7250) and ATP (A7699) were all purchased from Sigma-Aldrich. Apocynin (17838) was obtained from Merck (Molshein, France), Cathepsin B inhibitor (CA074Me) from Calbiochem (VWR International, Fontenay-sous-Bois, France), Flag-TRAIL from Enzo Life sciences
(Villeurbanne, France) and water-soluble Prob (FP-288653) from Interchim (Montluçon, France).

Viability assay. Cells were seeded in 24-well dishes (Falcon, D Dutscher, Brumath, France) at $50000 \mathrm{cells} / \mathrm{ml}$ the day before treatment with LXR agonists. After treatment, cells were washed two times with PBS and fixed with $100 \%$ ethanol for $30 \mathrm{~min}$ before crystal violet staining. Crystal violet was then resuspended in $33 \%$ acetic acid and OD was read at $590 \mathrm{~nm}$ with a Wallac 2 spectophotometer (Perkin-Elmer, Villebon sur Yvette, France).

Cell death determination. For Annexin V/7-amino-actinomycin D (7-AAD) labeling, cells were seeded in 24-well dishes as described above. After treatment with different LXR agonists for $24 \mathrm{~h}$, cells were harvested and washed two times with cold PBS and then incubated with Annexin V (FITC)/7-AAD kit (BD Biosciences, Le Pont de Claix, France) according to the manufacturer's protocol. Annexin $\mathrm{V}$ binding and 7-AAD incorporation were detected by an LSRII flow cytometer (BD Biosciences) and analyzed using Flowjo software (Tristar, Ashland, OR, USA). 
Staining of nuclear chromatin with Hoechst 33342 was used for identification of morphologic changes by fluorescence microscopy.

Cell viability was also determined by using a trypan blue dye exclusion assay.

For LDH release assay, cells were seeded the day before treatment with LXR agonists and treated in optimem medium (Invitrogen, Life Technologies, Villebon sur Yvette, France) during $24 \mathrm{~h}$. The supernatant was harvested, centrifuged for $4 \mathrm{~min}$ at $420 \times \mathrm{g}$ and finally incubated with Cytotox96-release kit (Promega, Charbonnières, France; G1780) according to the manufacturer's instructions.

Caspase activity. To assess caspase-1, or caspase-3/7 activity, the FAMYVAD-FMK or SR-DEVD-FMK fluorescent probes (AbdSerotec, Colmar, France) binding to cleaved caspases were used according to the manufacturer's instructions. Briefly, 250000 cells were concomitantly incubated with probes for $1 \mathrm{~h}$ during the final hour of treatment with LXR agonists and then washed two times in apoptosis buffer before flow cytometry analysis.

ATP supernatant assay. Cells were incubated for the indicated times with either vehicle or different LXR agonists in RPMI 1640, 1\% BSA, 10mM HEPES (Gibco, Life Technologies) medium. Cell suspensions were then centrifuged at $425 \times g$ for $3 \mathrm{~min}$ at room temperature. Supernatants were transferred to a fresh tube. ATP measurement was done on supernatants using a luciferase/luciferine assay (G7570) from Promega according to the manufacturer's instructions with a Wallac 2 luminometer (Perkin-Elmer).

ASC pyroptosome purification. ASC complexes were isolated as previously described. ${ }^{28} 3 \times 10^{6}$ cells were treated during indicated times in 6-well plate and harvested by scrapping, then washed in ice-cold PBS and resuspended in $500 \mu \mathrm{l}$ ice-cold buffer $(20 \mathrm{mM}$ HEPES-KOH, pH 7.5, $150 \mathrm{mM} \mathrm{KCl}, 1 \% \mathrm{NP}-40$ $0.1 \mathrm{mM}$ PMSF, $1 \mathrm{mM}$ sodium orthovanadate and complete protease inhibitor mixture (CPIM), Roche). Cells were lysed by shearing 10 times through a 21-G needle and centrifuged at $330 \times \mathrm{g}$ for $10 \mathrm{~min}$ at $4{ }^{\circ} \mathrm{C}$. The pellets were washed twice in $1 \mathrm{ml}$ ice-cold PBS (centrifuged $330 \mathrm{~g}$ for $3 \mathrm{~min}$ at $4{ }^{\circ} \mathrm{C}$ ) and resuspended in $500 \mu \mathrm{l}$ PBS. Four millimolars disuccinimydyl suberate (from a fresh $100 \mathrm{mM}$ stock prepared from DSS equilibrated to RT and made up in dry DMSO) were added and the pellets were incubated at RT for $30 \mathrm{~min}$ with rotation. The samples were then centrifuged at $330 \times \mathrm{g}$ for $10 \mathrm{~min}$ at $4^{\circ} \mathrm{C}$. The supernatant was removed and the cross-linked pellets were resuspended in $30 \mu \mathrm{l}$ Laemmli sample buffer. The samples were boiled for $5 \mathrm{~min}$ at $95^{\circ} \mathrm{C}$ and analyzed by western blotting.

Immunoprecipitation. Cells $\left(50 \times 10^{6}\right)$ were lysed in $1 \mathrm{ml}$ lysis buffer $(20 \mathrm{mM}$ Tris $(\mathrm{pH} 7.5), 15 \mathrm{mM} \mathrm{KCl}, 1 \%$ CHAPS, $5 \mathrm{mM} \mathrm{MgCl} 2,1 \mathrm{mM}$ EDTA, $1 \mathrm{mM}$ EGTA and CPIM) for $30 \mathrm{~min}$ on ice. After centrifugation at $14000 \times \mathrm{g}$ at $4^{\circ} \mathrm{C}$ for $30 \mathrm{~min}$, supernatants were precleared during $2 \mathrm{~h}$ at $4^{\circ} \mathrm{C}$ in the presence of $30 \mu \mathrm{l}$ of mixed Sepharose 6B (6B100, Sigma-Aldrich) and protein G (17-0618-01, Amersham, GE Healthcare, Velizy-Villacoublay, France). After centrifugation at $1000 \times g$ for 3 min the supernatant was incubated with anti-LXR $\beta$ antibody (PP-K8917, Perseus Proteomics) $(2 \mu \mathrm{g} / \mathrm{ml})$ at $4{ }^{\circ} \mathrm{C}$ for $20 \mathrm{~h}$ and during the last hour with $40 \mu \mathrm{l}$ of mixed Sepharose. The precipitates were washed four times in lysis buffer and analyzed by immunoblotting.

Western blotting. Whole-cell lysates were prepared as described previously, ${ }^{29}$ by lysing the cells in boiling buffer ( $1 \%$ SDS, $1 \mathrm{mM}$ sodium vanadate, $10 \mathrm{mM}$ Tris (pH 7.4)) in the presence of CPIM. The viscosity of the samples was reduced by sonication. Whole-cell lysates or immunoprecipitation samples were separated by SDS-polyacrylamide gel electrophoresis, and electroblotted to a nitrocellulose membrane (GE Healthcare). After incubation for $2 \mathrm{~h}$ at RT by $5 \%$ nonfat milk in Tris-buffered saline- $0.1 \%$ Tween-20, membranes were incubated overnight with the primary antibody diluted in Tris-buffered saline-milk-Tween-20, washed, incubated with the secondary antibody for $30 \mathrm{~min}$ at RT, and washed again before analysis with a chemiluminescence detection kit (Amersham). The following mouse mAbs were used: anti- $\beta$-actin (A1978) and anti-Flag M2 (F3165) from Sigma-Aldrich, anti-pannexin-1 (H00024145-M07) from Abnova (Tebu, Le Perray en Yvelines, France), anti- LXR $\beta$ (PP-K8917-00) from Perseus Proteomics, anti-NLRP3 (AG-20B-0014) and anti-caspase-1 (AG-20B-0048) from Adipogen (COGER SAS, Paris, France). We also used rabbit pAbs anti-ASC (AL177) from Enzo Life Sciences, anti-cleaved caspase-3 (9661), anti-cleaved caspase-7 (9491), anti-cleaved caspase-8 (9496) and anti-cleaved caspase-9 (9501) from Cell Signaling Technology (St. Quentin, France). Secondary Abs HRP-conjugated polyclonal goat anti-mouse and swine anti-rabbit immunoglobulins (Jackson ImmunoResearch, Interchim) were also used.
Quantitative PCR analysis. Total RNA was extracted using Trizol (Invitrogen). One hundred to three hundred nanograms of RNA was reversetranscribed into cDNA using M-MLV reverse transcriptase, Random Primers and RNAseOUT inhibitor (Invitrogen). cDNA were quantified by real-time PCR using Power SYBR Green Real-time PCR kit (Life Technologies) on a Fast7500 detection system (Applied Biosystems, Life Technologies). Relative mRNA levels were determined using the $\Delta \Delta \mathrm{Ct}$ method. Values were expressed relative to cyclophilin A, gapdh and $\beta$-actin levels. The sequences of the oligonucleotides used are described in Supplementary Table 1.

IF and in situ PLA. Cells $(150000)$ were seeded in 12-well dishes containing a cover glass (631-0150, VWR International), which was pretreated for $10 \mathrm{~min}$ with Poly-L-Lysin (P4707, Sigma-Aldrich). The following day cells were treated or not with LXR agonists for the indicated times. Cells were washed, fixed with $4 \%$ PFA at $4{ }^{\circ} \mathrm{C}$ for $10 \mathrm{~min}$ and permeabilized using a PBS, $0.5 \%$ BSA, $0.1 \%$ Saponin (47036, SigmaAldrich) buffer for $20 \mathrm{~min}$ at RT. Samples were incubated $2 \mathrm{~h}$ at RT with primary antibodies.

For IF experiments, cells were washed two times, and incubated with secondary Alexa488- or Alexa568-coupled anti-mouse or anti-rabbit for $30 \mathrm{~min}$ at RT. For PLA experiments, after washing primary antibodies, cells were then incubated with the appropriate probes (Sigma-Aldrich) during $1 \mathrm{~h}$ at $37^{\circ} \mathrm{C}$ and washed two times. Probes were then ligated for $30 \mathrm{~min}$ at $37^{\circ} \mathrm{C}$, washed two times in Buffer $\mathrm{A}$ and amplified using the manufacturer's polymerase for $100 \mathrm{~min}$ at $37^{\circ} \mathrm{C}$ in the dark.

For both experiments, cover glasses were mounted on a drop of Mounting Medium containing Dapi (Duo82040, Sigma-Aldrich) for $15 \mathrm{~min}$ in the dark on a microscopy slide (045796, Dutscher, Brumath, France). Slides were imaged using a CDD equipped upright microscope (Zeiss, Marly le Roi, France) and $\times 63,1.4$ NA objective.

The following antibodies were used for IF and PLA: mouse anti-pannexin 1 (1/250, H00024145-M07, Abnova), rabbit anti-LXR $\beta$ (1/250, ab106473, Abcam), anti-rabbit PLUS probe (1/5, Du092002, Sigma-Aldrich), anti-mouse MINUS probe (1/5, Duo92004, Sigma-Aldrich), goat anti-mouse Alexa488 (1/1000, A11029, Invitrogen), goat anti-rabbit Alexa568 (1/1000, A11036, Invitrogen), donkey antimouse Alexa568 (1/1000, A10037, Invitrogen). Cholera toxin (C-34775, Molecular Probes, Life Technologies) was used to stain membranes specifically.

Plasmid constructs. The human $\operatorname{LXR} \beta$ construct was obtained by inserting the human $\operatorname{LXR} \beta$ (1386 bp) coding sequence in the multicloning site of the $\mathrm{p} 3 \mathrm{X}$ FLAG plasmid (Sigma-Aldrich). The sequences of the oligonucleotides used are described in Supplementary Table 1.

Stable and transient transfections. Human $293 \mathrm{~T}$ cells were transiently transfected for $24 \mathrm{~h}$ with expression plasmids using the JetPRIME reagent (PolyPlus transfection), according to the manufacturer's instructions. Briefly, 50000 cells were seeded in 24-well plates one day before transfection. The next day, $0.5 \mu \mathrm{g}$ of plasmid was mixed with $1 \mu$ l of JetPRIME reagent in $50 \mu$ of JetPRIME buffer. After a $10 \mathrm{~min}$ incubation at room temperature, the mix was added to the cells and medium was removed and replaced $4 \mathrm{~h}$ later. The next day, cells were used for T0901317 treatment and further experiments. For stable transfections, neomycin (11811-064, Gibco) was used at $200 \mu \mathrm{g} / \mathrm{ml}$ to select transduced cells.

HCT116 cells were transfected with the INTERFERin transfection reagent (Polyplus transfection) according to the manufacturer's instructions. Briefly, 50000 cells were seeded in 24-well plates one day before transfection. Silencer Select siRNAs specific for the target gene or Negative siRNA control (Life Technologies) diluted in serum-free medium were incubated with INTERFERin for $10 \mathrm{~min}$ at room temperature and added to the cells to a final concentration of $1 \mathrm{nM}$. Twenty-four hours after transfection, the cells were treated before further experiments. The following siRNA were used: $\mid \operatorname{xr} \alpha$ (s19568), $\operatorname{|xr} \beta$ (s14685), nlrp3 (s41556), asc (s26509), p2 × 7 (s9959), pannexin-1 (s24427), vdac1 (s14769), vdac2 (s14771) or control (AM4611).

Cells were transduced with MISSION Lentiviral Transduction Particles (SigmaAldrich) to silence human caspase-1 (HCT116) or murine $\operatorname{lxr} \beta$, caspase-1, nlrp3 (CT26) or with negative control particles according to the manufacturer's instructions. Briefly, 16000 cells were plated in 96-well plates and the next day, lentiviral particles (multiplicity of infection tested between 0.5 and 5) were added in the presence $8 \mu \mathrm{g} / \mathrm{ml}$ of hexadimethrine bromide (Sigma-Aldrich) for $20 \mathrm{~h}$. Then, the medium was removed and replaced with fresh medium containing $5 \mu \mathrm{g} / \mathrm{ml}$ (HCT116) or $10 \mu \mathrm{g} / \mathrm{ml}$ (CT26) of puromycin (Sigma-Aldrich) every 3 days until resistant colonies were obtained. 
Surface plasmon resonance analysis. The design and fabrication of homemade chips compatible with surface plasmon resonance were performed as previously published with the help of the MIMENTO technological platform (Besançon, France)..$^{30}$ Biacore experiments were performed with the Biacore 2000 apparatus (GE Healthcare) at $25^{\circ} \mathrm{C}$ with a flow rate of $2-30 \mu / / m i n$. Human LXR $\beta$ and rat serum albumin (both at $10 \mu \mathrm{g} / \mathrm{ml}$ ) were immobilized on chemically activated self-assembly monolayers of 11-mercapto-1-undecanol (11-MUOH) and 16-mercapto-1-hexadecanoic acid (16-MHA; $90 / 10$ by mole). Real-time monitoring allowed the control of 8.8 and $8.1 \mathrm{fmol} / \mathrm{mm}^{2}$ of immobilized proteins in each experiment. Ten nanomolars of human $\operatorname{LXR} \beta$ were injected at $20 \mu \mathrm{l} / \mathrm{min}$ in PBS $0.05 \%$ Tween $(\mathrm{pH} 7.4)$ buffer according to the Kinject procedure (association time, $3 \mathrm{~min}$; dissociation time, $3 \mathrm{~min}$ ).

Mice. All animals were bred and maintained according to both the FELASA and the Animal Experimental Ethics Committee Guidelines (University of Burgundy, France). Animals used were between 6 and 22 weeks of age. Female BALB/C mice (aged 6-8 weeks) were obtained from Charles River Laboratories (Saint Germain sur l'Arbresle, France). One million cells of either CT26 WT or shCT26 were subcutaneously injected in a volume of $100 \mu \mathrm{l}$ of PBS. Tumors were measured with caliper three times a week. Some mice were treated daily with i.p. injections of T0901317 (30 or $60 \mathrm{mg} / \mathrm{kg}$, dissolved in 50\% DMSO and 50\% PBS) or vehicle (50\% DMSO, $50 \%$ PBS). Some mice were treated with daily i.p. injections of Prob $(200 \mathrm{mg} / \mathrm{kg})$ dissolved in PBS or vehicle alone.

Statistical analyses. In vitro results are shown as means \pm S.D., in vivo results are shown as means \pm S.E.M. and comparisons of data sets were performed using unpaired Student's t-test (test group compared with control group). For human experiments, paired $t$-test was used to compare samples from the same patients before and after $1 \mathrm{~h}$ of T0901317 treatment. Differences in survival in the tumor growth experiments were assessed using Log rank (Mantel-Cox) test. We performed statistical calculations with GraphPad Prism 5 (La Jolla, CA, USA). All P-values were two-tailed.

\section{Conflict of Interest}

The authors declare no conflict of interest.

Acknowledgements. We thank JM Lobaccaro for providing material. This work was supported by Ligue contre le cancer comité Grand-Est and by a French Government grant managed by the French National Research Agency under the program 'Investissements d'Avenir' with reference ANR-11-LABX-0021 (Lipstic Labex). FG team is 'Equipe labelisée Ligue Nationale Contre le Cancer'. VD is the recipient of a 'poste d'accueil INSERM'. The authors are supported by grants from the Ligue Nationale contre le Cancer (FC, FV and SC), the Association pour la Recherche Contre le Cancer (ARC) (MB, GM), the Conseil Régional Bourgogne/ INSERM (HB).

1. Wojcicka G, Jamroz-Wisniewska A, Horoszewicz K, Beltowski J. Liver X receptors (LXRs). Part I: structure, function, regulation of activity, and role in lipid metabolism. Postepy Hig Med Dosw (Online) 2007; 61: 736-759.

2. Vedin LL, Lewandowski SA, Parini P, Gustafsson JA, Steffensen KR. The oxysterol receptor LXR inhibits proliferation of human breast cancer cells. Carcinogenesis 2009; 30: 575-579.

3. Fukuchi J, Kokontis JM, Hiipakka RA, Chuu CP, Liao S. Antiproliferative effect of liver $X$ receptor agonists on LNCaP human prostate cancer cells. Cancer Res 2004; 64: 7686-7689.

4. Chuu CP, Hiipakka RA, Kokontis JM, Fukuchi J, Chen RY, Liao S. Inhibition of tumor growth and progression of $\mathrm{LNCaP}$ prostate cancer cells in athymic mice by androgen and liver X receptor agonist. Cancer Res 2006; 66: 6482-6486.

5. Pommier AJ, Alves G, Viennois E, Bernard S, Communal Y, Sion B et al. Liver X Receptor activation downregulates AKT survival signaling in lipid rafts and induces apoptosis of prostate cancer cells. Oncogene 2010; 29: 2712-2723.
6. Scoles DR, Xu X, Wang H, Tran H, Taylor-Harding B, Li A et al. Liver X receptor agonist inhibits proliferation of ovarian carcinoma cells stimulated by oxidized low density lipoprotein. Gynecol Oncol 2010; 116: 109-116.

7. Guo D, Reinitz F, Youssef M, Hong C, Nathanson D, Akhavan D et al. An LXR agonist promotes glioblastoma cell death through inhibition of an EGFR/AKT/SREBP-1/LDLRdependent pathway. Cancer Discov 2011; 1: 442-456.

8. Uno S, Endo K, Jeong $\mathrm{Y}$, Kawana K, Miyachi H, Hashimoto $\mathrm{Y}$ et al. Suppression of beta-catenin signaling by liver $X$ receptor ligands. Biochem Pharmacol 2009; 77: 186-195.

9. Sasso GL, Bovenga F, Murzilli S, Salvatore L, Di Tullio G, Martelli N et al. Liver X receptors inhibit proliferation of human colorectal cancer cells and growth of intestinal tumors in mice. Gastroenterology 2013; 144: 1497-1507.

10. Kepp O, Galluzzi L, Zitvogel L, Kroemer G. Pyroptosis - a cell death modality of its kind? Eur J Immunol 2010; 40: 627-630.

11. Schroder K, Tschopp J. The inflammasomes. Cell 2010; 140: 821-832.

12. Fernandes-Alnemri T, Wu J, Yu JW, Datta P, Miller B, Jankowski $W$ et al. The pyroptosome: a supramolecular assembly of ASC dimers mediating inflammatory cell death via caspase-1 activation. Cell Death Differ 2007; 14: 1590-1604.

13. Di Virgilio F. Purines, purinergic receptors, and cancer. Cancer Res 2012; 72: 5441-5447.

14. Chekeni FB, Elliott MR, Sandilos JK, Walk SF, Kinchen JM, Lazarowski ER et al. Pannexin 1 channels mediate 'find-me' signal release and membrane permeability during apoptosis. Nature 2010; 467: 863-867.

15. Chuu CP. Modulation of liver $\mathrm{X}$ receptor signaling as a prevention and therapy for colon cancer. Med Hypotheses 2011; 76: 697-699.

16. Kokontis JM, Hay N, Liao S. Progression of LNCaP prostate tumor cells during androgen deprivation: hormone-independent growth, repression of proliferation by androgen, and role for p27Kip1 in androgen-induced cell cycle arrest. Mol Endocrinol 1998; 12: 941-953.

17. Pascual-Garcia $M$, Valledor AF. Biological roles of liver $X$ receptors in immune cells. Arch Immunol Ther Exp (Warsz) 2012; 60: 235-249.

18. Zhu R, Ou Z, Ruan X, Gong J. Role of liver X receptors in cholesterol efflux and inflammatory signaling (review). Mol Med Rep 2012; 5: 895-900.

19. Spyridon M, Moraes LA, Jones Cl, Sage T, Sasikumar P, Bucci G et al. LXR as a novel antithrombotic target. Blood 2011; 117: 5751-5761.

20. Hozoji M, Munehira Y, Ikeda Y, Makishima M, Matsuo M, Kioka N et al. Direct interaction of nuclear liver X receptor-beta with ABCA1 modulates cholesterol efflux. J Biol Chem 2008; 283: 30057-30063.

21. Hozoji-Inada M, Munehira Y, Nagao K, Kioka N, Ueda K. Liver X receptor beta (LXRbeta) interacts directly with ATP-binding cassette A1 (ABCA1) to promote high density lipoprotein formation during acute cholesterol accumulation. J Biol Chem 2011; 286: 20117-20124.

22. Allen IC, TeKippe EM, Woodford RM, Uronis JM, Holl EK, Rogers AB et al. The NLRP3 inflammasome functions as a negative regulator of tumorigenesis during colitis-associated cancer. J Exp Med 2010; 207: 1045-1056.

23. Zaki MH, Boyd KL, Vogel P, Kastan MB, Lamkanfi M, Kanneganti TD. The NLRP3 inflammasome protects against loss of epithelial integrity and mortality during experimental colitis. Immunity 2010; 32: 379-391.

24. Dupaul-Chicoine J, Yeretssian G, Doiron K, Bergstrom KS, McIntire CR, LeBlanc PM et al. Control of intestinal homeostasis, colitis, and colitis-associated colorectal cancer by the inflammatory caspases. Immunity 2010; 32: 367-378.

25. Lamkanfi M, Dixit VM. Inflammasomes and their roles in health and disease. Annu Rev Cell Dev Biol 2012; 28: 137-161.

26. Wang Q, Imamura R, Motani K, Kushiyama $\mathrm{H}$, Nagata $\mathrm{S}$, Suda $\mathrm{T}$. Pyroptotic cells externalize eat-me and release find-me signals and are efficiently engulfed by macrophages. Int Immunol 2013; 25: 363-372.

27. Rebe C, Raveneau M, Chevriaux A, Lakomy D, Sberna AL, Costa A et al. Induction of transglutaminase 2 by a liver $X$ receptor/retinoic acid receptor alpha pathway increases the clearance of apoptotic cells by human macrophages. Circ Res 2009; 105: 393-401.

28. Coll RC, O'Neill LA. The cytokine release inhibitory drug CRID3 targets ASC oligomerisation in the NLRP3 and AIM2 inflammasomes. PLoS One 2011; 6: e29539.

29. Rebe C, Cathelin S, Launay S, Filomenko R, Prevotat L, L'Ollivier C et al. Caspase-8 prevents sustained activation of NF-kappaB in monocytes undergoing macrophagic differentiation. Blood 2007; 109: 1442-1450

30. Boireau W, Rouleau A, Lucchi G, Ducoroy P. Revisited BIA-MS combination: entire "on-achip" processing leading to the proteins identification at low femtomole to sub-femtomole levels. Biosens Bioelectron 2009; 24: 1121-1127. 